\title{
Contradictory Discourses of Protection and Control in Transnational Asylum Law
}

\section{CAROL BOHMER \& AMY SHUMAN}

For immigration authorities, the goal of asylum hearings is to differentiate between economic migrants and legitimate political asylum seekers. However, in the stories asylum seekers tell, these categories often blur. Nevertheless, the asylum process uses this differentiation to conceal inequities in the system, and to justify denials. This article examines political asylum as a transnational and culturally local process and argues that contradictions between protection and control underlie some of the seemingly absurd denials of asylum applications.

* Key words transnational, narrative, asylum seekers, human rights

\section{Introduction}

Political asylum is characterized not only by the familiar destabilizing dimensions of transnationalism, including displacement, migration, and border conflicts, but also by contradictory discourses of protection and control and by conflicting goals of humanitarianism and state interests. Political asylum seekers, like other migrants, rely on transnational networks of affiliation, but unlike other migrants, political asylum seekers live in exile, a condition that can make any sense of belonging fragile and tentative.

Asylum hearings insert a transnational discourse into national contexts. Asylum law is transnational, affording or even insisting on consistency across national bureaucracies. At the same time, asylum seekers' experiences of persecution are so local as to be almost untranslatable. It is incumbent on asylum seekers to find a way to do this translation, to present their experiences sufficiently uniquely to warrant personal protection, and also to represent their experiences in recognizable (transnational) terms. This is an example of what Saskia Sassen describes as "global logics...constituted inside 
the nation state and the state apparatus itself" (2007: 431). In asylum hearings, the global logics of protection are constituted not only within but also against local logics of boundary maintenance, surveillance, and suspicion.

In a parallel universe, political asylum seekers operate in transnational, often illegal networks that defy national borders in the production of fake passports, in the illegal transportation of people across borders, and in ongoing networks creating diasporas that have their own borders, but not those of the nation state. Increasing restrictions and obstacles to asylum create the need for all kinds of support, including, especially in the US, financial support. People need other sorts of support from those who know how the process works to combat the difficulties of obtaining asylum. The underground networks are also transnational and are increasing in scope as states put in place policies that virtually require smuggling as a means of escape. In addition to describing these networks of transnational belonging, asylum seekers describe experiences of dislocation and disconnectedness. Asylum hearings often exacerbate the experience of disconnectedness and humiliation. We understand these discourses of personal experience, evident in the narratives we have collected from asylum seekers, as part of the contradictions in the public discourses about political asylum and human rights.

\section{Narratives of the Asylum Process}

Our work is based on ethnographic research with asylum seekers and their advocates (both community workers and lawyers) and includes observations of asylum hearings in the United States and Great Britain. As a collaborative team of an anthropologist/folklorist/narrative scholar and a lawyer/sociologist, we have been interested both in documenting the asylum system and in assisting asylum seekers to prepare for their hearings. Carol Bohmer (lawyer/sociologist) began offering pro bono legal services at CRIS (Community Refugee and Immigration Services) in Columbus, Ohio and then continued her work in New England and London. In addition to our general observations of the asylum process, we have focused on the discourses of asylum including the stories asylum seekers tell when they first ask for assistance from community organizations; the presentation of whatever will count as evidence in the hearing; and media, policy, and other public discussions (Shuman and Bohmer 2004). The contradictions between protection and control, humanitarian and state interests, are evident in these discourses. In other words, the transnational is not located only in public transnational contexts but also in local, culturally situated, personal accounts.

Although asylum officers make clear distinctions between economic migrants and legitimate political asylum seekers, in the stories asylum seekers initially tell (when they first seek help from lawyers and community service agencies), these categories often blur. In our interviews, asylum seekers often explained the initial motivations for their political activism as efforts to 
counter corruption or to change discriminatory policies. For example, a Libyan former banker described his involvement in an organization that was designed to help young people get married. He was detained and tortured for "demanding a better life for Libyans." We heard similar accounts from other asylum seekers, including a Guinean woman who protested against the president who was "not doing anything for our country" and a Cameroonian woman who protested for the rights of English speaking Cameroonians who were attending an English speaking university to receive accreditation for their studies. All of these asylum seekers were working to improve their conditions in their homelands; in the U.S. and England, where they now have asylum, they continue to describe their struggles in terms of a desire for a better life. All three were detained and tortured, escaped and fled to countries offering safe haven. What differentiates them from economic migrants (in legal terms) is the fact that they protested and were persecuted before leaving. This is a huge difference for the asylum officials, but the categories are remarkably undifferentiated in the narratives of some asylum seekers. In some cases, they emphasize this point (to the detriment of their cases) by insisting that they were not following abstract ideologies, but were instead acting out of necessity. The Anglophone Cameroonian explains that quite suddenly, the French authorities determined that her studies at the only English speaking university in Cameroon would not qualify her for accreditation as a nurse. She says:

I decided to join the organization because I realized that I really had to do something.

It wasn't going to get better. I needed to do something. So I joined and I started getting involved. ${ }^{1}$

Many of the asylum seekers whose cases we followed were more interested in differentiating between criminal activity and their own, justifiable, actions. The Anglophone Cameroonian woman explains:

We were just asking for the education. We didn't hurt anyone We were treated like criminals

Asylum procedures often perpetuate the association with criminality, not only by detaining applicants but also through discourses about safe borders and about the concern that asylum seekers have been involved in armed struggle. Ranjana Khanna sees both the interests of the state and the interests of the asylum seeker as based on concepts of security:

'Asylum' draws on a discourse of sovereignty that blurs some of the distinctions between home and abroad in a similar fashion to Hobbes' notion of sovereign right. In its modern incarnation, asylum has to assume a narrative of emergency and security embodied in the asylum 
seeker herself. She must be in danger from her home state for the asylum awarding state to decide whether to take her in or not. She must be functioning within a language of need, rather than simply desire, and once given refuge from this spatial and temporal limboshe has departed but has not fully arrived-she will apparently be protected by the new state (2006: 475).

\section{Asylum Law and the Transnational Subject}

In the discussion that follows, we consider how the asylum seeker has emerged as a transnational subject whose displacement warrants relocation in ways that economic hardship does not (according to asylum law). We review briefly the history of asylum law to understand how the category of asylum seeker came to encompass a variety of displaced persons, including groups targeted for persecution on the basis of their identity, individual high-profile political activists, and individuals persecuted for particular cultural or religious practices. The legal discourses of asylum locate persecution in local cultural contexts weighed against transcultural/transnational legal categories. On a personal level, exile is always both transnational and local. The networks created in exile are networks of necessity, suspicion, and survival.

Political asylum occupies a tenuous position between national and international law, between nation states and transnational bodies. Asylum trespasses national borders, creating a transnational discourse, transnational informal (and often illegal) networks of transport and communication, and transnational identities (sometimes non-identities). ${ }^{2}$ Political asylum hearings utilize transnational, national, and local categories of culture, persecution, and identity strategically, often to play the humanitarian and state interests against each other. Here we examine some of these competing interests, especially the differentiation between asylum seekers and economic migrants, to explore how the transnational is employed both to create lofty transnational humanitarian interests and to pit those against the interests of the state.

Asylum law relies on international human rights laws designed to protect people from persecution when their own countries do not. However, as Charles Piot (2006) points out, the political asylum seeker, a seemingly transnational subject governed by international human rights law, also represents not so hidden binary oppositions between western and nonwestern, civilized and barbaric, or first and third world. These binary oppositions represent not only differentiations among those countries willing to offer safe haven (as a part of western democracy, for example), and those countries that are sites of conflict, but also, and importantly, differentiations that are necessary to preserve the idea of sites of safety and safe haven. In other words, it's not only the case that people in dangerous places move to places of safety. By offering political asylum, western countries declare themselves as places free of certain kinds of persecution. A mark of becoming a 'western' country is the ability to be part of the persecution-free zone, as can 
be illustrated by the automatic inclusion of the ten recent EU accession countries on the UK list of 'safe third countries' from which it is virtually impossible to obtain asylum, something the Roma have found to their cost. In addition to facing many obstacles, political asylum seekers, ${ }^{3}$ must also prove both that they are not economic migrants and also that the persecution they have suffered is not the kind of ordinary violence one might experience in the West.

Refugees and asylum seekers are protected by the 1951 United Nations Convention Relating to the Status of Refugees, which was limited to protecting European refugees after World War II, but a 1967 Protocol removed the geographical and time limits, thus expanding the scope of the treaties to the current system of asylum. The definition of asylum requires that someone show a: "well-founded fear of persecution on account of race, religion, nationality, membership in a particular social group, or political opinion." There are now 147 signatories to the Convention or the Protocol or both. States have incorporated these agreements into their national laws, which they then implement.

The European Union also has Europe wide agreements on human rights that have been incorporated into the national laws of members. EU wide agreements attempt to make uniform policies toward asylum. This stems from fact that the international frontiers around Europe are now the relevant borders, rather than national borders. The EU has in place a burden sharing agreement which determines which Member State will be responsible for an asylum application lodged in the EU, known as the Dublin Convention, and after 2003 Dublin II regulations (O'Sullivan 2009: 242). But the agreement does nothing to harmonize the definition of a refugee or the standards for making decisions in asylum cases; for this reason it has been considered to be only a limited success (ibid.). There is still variation from state to state about the handling of asylum seekers which has resulted in some acrimony among EU states.

Although asylum policies stem from the Universal Declaration of Human Rights, asylum is quickly differentiated from the protection of human rights. Khanna points out:

Article 14 of the 1948 Universal Declaration of Human Rights, is the only article that is immediately qualified. This qualification demonstrates quite clearly what is singular about the right to seek asylum on the declaration, and indeed what seems so anachronistic about it. There is no human right to asylum as such. There is only the right to seek asylum, and to enjoy it if it is granted. Asylum will be considered only if the state considers endangerment to be caused by a form of political persecution. In other words, asylum is the right of the state and is not the right of a human (2006: 474). 
With the exception of Germany, the right to asylum belongs to the state and not to the individual seeking it (Schuster 2003). Khanna's argument is useful for understanding control and protection as not only contradictions, as they seem to be in asylum hearings, but also as part of the same process. She discusses political asylum in the context of other asylums, especially insane asylums, where protection and control are the same. Although in both the ideal terms of public policy and in the everyday conversations of asylum seekers, political asylum is discussed in terms of freedom and safe haven, Khanna points out that the actual experience is more about controlled movement, and conditional citizenship. Nations sign on to international agreements because they are interested in the larger regulation of displaced persons. Thus they often make decisions designed to afford regulation rather than protection. They may be more interested in signing on to an international agreement because it creates the possibility that other nations will comply. Being bound by an international agreement also provides individual nations with a justification for asylum policies which may be more repressive than the people would prefer (Schain 2008: 59).

Discourses of responsibility, embarrassment, and humiliation also occur at all levels, the transnational, national, and local. In the most obvious sense, nations bear some responsibility and embarrassment for displaced persons as a result of civil wars. Asylum seekers sometimes prefer to talk about their sense of responsibility in making risky choices than about the shame they experience being persecuted. These complex intertwined discourses get translated into discourses of need and urgency. They are deeply implicated in the differentiations we make between the asylum seeker, defined by urgency, and the economic migrant, defined by the desire for a better life, but of course, both groups experience urgency and desire as the same. In asylum hearings, they are differentiated by the concept of 'well-founded fear': the asylum seeker's fear of being persecuted in the future replaces the present emergency of the need to leave. Khanna (2006: 484) argues that the future seems irrelevant to those in a state of emergency. However, for the asylum official, only the future is relevant. Political asylum is about the future, even though it relies on testimony from the past.

Transnational political asylum agreements are intended to afford certain kinds of solutions. In reality, states that sign on may be reluctant to follow through with the obligations they undertake; the agreements are subject to misuse, or at least narrow interpretation. This is often because the transnational agreements may conflict with national interests. Elsewhere we have written of the ways in which the obligation to provide safe haven may clash with long recognized principle that communities must protect themselves (Bohmer and Shuman 2007). States use refugee law, which is international, at the national level to achieve their own aims, so the results are inconsistent (Kneebone 2009). As Erika Feller, Assistant High CommissionerProtection, UNHCR puts it: "Finding asylum can become a matter of chance 
in some regions, due to inconsistencies by States in applying Convention standards" (as quoted in Kneebone 2009: 29).

All of the concepts employed in the asylum evaluation process are of necessity transnational, designed to apply across national differences. What counts as persecution is supposed to be a translatable category. Asylum officials do consider particular circumstances, but these, too, are translated into comparative terms, and a uniform (transnational) means of assessment is applied to all countries. The UK attempts to provide national consistency by the use of 'country condition reports' which individual asylum officers and judges are supposed to rely on in their decision making. The US, while it does not produce formal country conditions reports to increase the consistency of asylum decisions, nevertheless relies heavily on third party documentation, including US State Department reports. In the following discussion, we will consider denials of particular cases and review these with regard to these condition reports. ${ }^{4}$

A Burmese woman who had been arrested and interrogated several times as a member of the Arakan League for Democracy (ALD) was denied asylum because "the events you described do not constitute past persecution." The asylum officer reported that she had left Burma (after being arrested) but upon her return, "You were not detained or arrested you were just questioned and this does not rise to the level of persecution." The official does not deny that the applicant was arrested, detained, and interrogated because of her political activities. The official's denial is based on insufficient fear of return to Burma. He wrote:

You also claim to have a fear of future persecution. To establish a wellfounded fear of persecution, an asylum applicant must show that her fear is both subjectively genuine and objectively reasonable. An asylum applicant may establish an objectively reasonable fear by demonstrating that there is a reasonable possibility of suffering persecution...you have not established that you possess any characteristic that the Burmese government is seeking to overcome (USCIS: 2006).

According to the official conditions of countries report, members of the ADL have gone into exile to escape persecution. Thus it makes sense that the Burmese woman would, as she claimed, leave the country to escape persecution. She says she returned to undertake further political work. She took a risk, and she believed that she was in danger, but a decision to take a risk can look like a determination that the asylum seeker is not really in danger. The Burmese woman's account was regarded as inconsistent: why (the officials ask) would someone who had been arrested, and who was so afraid of persecution that she left the country, return? Similarly, the Cameroonian woman we mentioned above was denied asylum because of inconsistencies. The asylum officer wrote: "Your testimony about your conversations with 
your activist mother and your reasons for continuing to fear persecution in Cameroon was inconsistent in material respects."

However, the officer acknowledges that the applicant and her family were persecuted. The report states:

While imprisoned you were mistreated and raped. After you left the country in 2004, your brother was killed because of your activities with the SCNC. Your mother has also been arrested several times because of her work.

Basically, the asylum official says that the Cameroonian woman failed to provide a good argument that the Cameroon government was still interested in harming her. The Cameroonian woman's lawyers were aware that there was a general perception of fraud among Cameroonian asylum seekers, and this contributed to their suspicions raised by what they saw as inconsistencies in her testimony. The officials did not challenge her account explicitly. Rather, they acknowledged her claim to persecution and instead challenged her on the basis of what seemed to them to be an inconsistency in her response to questions about conversations with her mother. She was granted a second hearing in which, according to the officials, she also failed to provide an adequate account of her conversations with her mother. In an unusual development, her lawyers managed to get the case reopened by a senior officer within USCIS who decided that she was in fact entitled to asylum.

A specific person's testimony is measured against both informal assessments such as this and more formal assessments referenced in the report on conditions in a particular country. Thus the testimony can be inconsistent in several ways. It can be internally inconsistent, for example when the Cameroonian woman mentioned seemingly inconsistent dates for her conversations with her mother. It can be inconsistent with the asylum official's assessment of what makes sense, for example in the Burmese woman's choice to return to Burma after she had fled detention. And it can be inconsistent with reports on the conditions in the country. Importantly, all three of these kinds of inconsistency are perceptions made by the asylum official who presumes his/her evaluation to be not only consistent but also uniform, transnational, applicable across national and cultural difference. In the process of translating across these scales of difference, the asylum seeker may be translated from a person with an emergency into a person seeking a better life. But a life without persecution is always a better life. Because these categories always overlap, the translation is not difficult. The burden rests on asylum seekers to differentiate themselves from economic migrants. ${ }^{5}$

\section{The Transnational and the Local}

Asylum law is created at the transnational level but implemented at the local level where officials exercise discretion. The transnational becomes local on 
the ground, when different asylum officers and lower court judges exercise their discretion interpreting the law to decide which set of events count as persecution and whether the category is a valid one under the law. Particularly in the US, this results in different outcomes for similar sets of facts depending on where one's case is heard. Studies have shown vastly different outcomes in different jurisdictions for cases that appear to be similar ${ }^{6}$. Lawyers know this and, where possible, try to send clients to make their claim in another area.

The evaluation of asylum claims also is local in another sense. In some countries (for instance, the UK), following the 1951 Convention, a claimant must show that it is unsafe for her/him to return to any part of her/his country. If local conditions would make it possible to live elsewhere in the country, the asylum seeker will not obtain asylum. The recognition that local conditions vary can trump the recognition of some cultural conditions, such as the assumption that a woman in a patriarchal society could live without male support in an area away from her family. In the US, however, the definition of refugee goes beyond that of the Convention by including the phrase "whether or not the person is outside his or her country of nationality or habitual residence" (Legomsky 2009: 131). So the asylum process in the US does not focus, as it often does in the UK, on whether there is some other part of the home country where she could be safe.

One fundamental problem with the implementation of the Convention is the differentiation between the categories of refugee and asylum seeker. Under the treaty a refugee is someone who is legally declared to fit the definition of the Convention before he is granted asylum in a host country. Those who flee persecution and claim asylum in the potential host country are called asylum seekers. However, in practice, these classifications are much more difficult to interpret. Many people flee 'bad situations' in their home countries. These bad situations can include persecution on the basis defined in the Convention, but it can also include general instability as a result of civil war, and the economic effects of such instability. It can encompass those who are simply seeking a better life, based on the hope that the new country will provide more opportunity to earn a living. Further, the asylum seeker must provide evidence of a fear of return. The refugee is granted safe haven based on already experienced persecution. 'A well-founded fear' is a crucial motive, and previous experiences of detention or rape are not sufficient. Under US asylum law, evidence of past persecution theoretically may be sufficient (as, for example, in the case of Holocaust survivors); in practice, however, it is very difficult to obtain asylum without proving a fear of future persecution. Teasing out the distinctions among these different motives for leaving and the different conditions in the home country is the most difficult task for the asylum system.

People have always fled persecution or fled bad situations (for example, the classic story of 'Fiddler on the Roof'; see also Ellick 2009). This phenomenon has become much more frequent, both for those who arrive 
legally and those who do not. The 1951 Convention was a response to a very different situation than the one that exists now, both in terms of sheer numbers and of social, economic and political world conditions. Many changes, including a vast increase in the sheer numbers of refugees, from 1.25 million refugees arising out of post World War II chaos (Kneebone 2009: 5), which gave rise to the 1951 Convention to 11.4 million under UNHCR mandate in 2008, not to mention the millions who are not under UNHCR protection or who are internally displaced (UNHCR, 2009).

\section{Economic and Political Refugees: Blurred Boundaries}

Like many transnational laws of the $20^{\text {th }}$ century, the 1951 Convention was not written with globalization in mind. As a result, it does not work any better than the national laws incorporating it in distinguishing between economic and political refugees. Such transnational treaties are harder to change than national laws as they require long and complex negotiations and the approval of a certain number of the participating countries before they come into effect.

Globalization provides people in refugee and economic migrant producing countries greater access to knowledge about alternatives. It does not mean that they are welcome elsewhere. As globalization has increased, so too have restrictions on entry. The Cold War determined 'freedom' based on a distinction between those who were not allowed to leave and those who were; people who managed to flee became a separate category, and they were welcomed on that basis by countries that permitted departure. There is no international right to immigrate to any country, only a right to leave, which is embodied in several transnational agreements. ${ }^{7}$ The international obligations embodied in the Convention and Protocol are about persecution, not about providing economic opportunity to those whose lives are bad. As long as a state can define the person as an economic migrant rather than a refugee, they are within their international rights not to allow them into the country. Within the letter of the Convention, this can be done by requiring proof of individual persecution based on belonging to one of the designated groups

With the end of the Cold War and the ability to leave the East, came the tightening up of immigration restrictions generally and asylum standards in particular (Schuster 2003: 6). Gregory Noll (2006) describes the shift in political asylum practices after the Cold War in terms of a reconfiguration in the negative obligations not to persecute people and the positive obligations to protect them. During the Cold War, the focus was on the negative obligations of strong states. After the Cold War, the focus shifted to the inability of weak states to protect individuals. Noll argues "Where states of origin are weak states, or even failed states, the image of the persecutor changes - so do the legal parameters of the asylum case, and so does the use of the culture argument" (ibid.: 493). He adds that in the weak state "culture 
grows into a factor of power, capable of persecution. The weak state emerges as an accomplice rather than the instigator of persecution" (ibid.: 495).

Each of the countries that have signed on to the Convention or the Protocol or both has different national priorities at different periods of time. These international agreements are likely to interfere with national priorities. On the national level, there are too many political priorities which may be considered more important than adhering to both the spirit and the law of the Convention. Given that national interests are more immediate, these political priorities trump the legal analysis inherent in the Convention. Recently many asylum receiving countries have worked very hard to minimize the number of asylum seekers and economic migrants who make it to their country. These efforts at border tightening more often have economic migrants as their target. But some of them seem to be directed at refugees more specifically (Legomsky 2009: 145 ). Even Canada, which has a higher rate of acceptance of asylum applications, has begun to require visas from those people who come from refugee producing countries (Macklin 2009: 105). It is apparent that only those who can show they are unlikely to seek asylum are given a visa. This includes such countries as Mexico and the Czech Republic which are not the obvious refugee producing countries but which have produced an increased number of asylum applicants recently (Citizenship and Immigration Canada 2009; Clifford 2009).

Many countries are also involved in interdiction to prevent influxes of boat people (who can of course be either asylum seekers or economic migrants, or both) from landing so they can take advantage of the asylum system (Legomsky 2009: 145). The US uses interdiction of vessels mostly to prevent Haitians from arriving, but also, more recently, ships from Cuba and other countries. That they may be refugees and not economic migrants was implicitly recognized by President Bush in 2005 when he said: "I have made it abundantly clear to the Coast Guard that we will turn back any refugee that attempts to reach our shore" (as quoted in Legomsky 2009: 147). The US Supreme Court has decided that intercepting people on the high seas without refugee screening was not a violation of US law or their transnational obligations (Sale v. Haitian Centers Council 1993). Scholars and the UNHCR reacted very negatively to this decision, because of the Convention obligation of non-refoulement, whereby states are bound not to return people to countries where they would be in danger of being tortured (Legomsky 2009: 163). But this case can be interpreted like so many national decisions on asylum in a number of developed countries, by claiming that asylum seekers are 'really' economic migrants.

At the border, the differentiation between the economic migrant and the asylum seeker provides a rationale for rejecting asylum petitions. Economic migrants are either welcomed as workers/guest workers or rejected as competing with citizens for jobs. Although not admitted as laborers, asylees are usually expected to work. This is especially true in the US because asylum seekers are provided no benefits except the right to work before asylum is 
granted, and relatively few after. Integration thus focuses on ensuring economic self-sufficiency as soon as possible. In other countries, like the UK, with a more extensive benefit system, a conflict exists between the provision of benefits and the sense that they are not deserved because the recipients are not 'real' asylum seekers, but rather are economic migrants. In Britain, foreigners who do not work are called 'layabouts.' This attitude may be caused by the system which pays for people and does not let them work. This initiates concerns about abuse of the benefits system as well as negative attitudes toward those who do not work. The Norwegians are concerned about what they see as potentially lifelong economic dependence on the state by some refugee groups, in contrast to early, economic migrants who took advantage of worker training programs and quickly became workers (Uhlin 2008). This discourse contradicts the U.S. efforts to differentiate between economic and political migrants. It points to an ambivalence (at best) about people who want opportunity. We accept asylum seekers who can prove the motive of needing a safe haven from persecution, but we expect them to make it on their own economically as soon as possible.

Economic and political refugees overlap and intersect, representing the intersections among the categories that produce them. The differentiation between economic and political refugees reproduces the relationship between strong and weak states, between liberal democracies and rogue states. Political asylum is not intended to change the class status of people, but it does promote opportunities. As our data show, safe haven and improving the conditions of life are the same. The data demonstrate that for the people we interviewed persecution often was connected to economic hardship, and safe haven is connected to well-being. Neither the Nazi era nor the Cold War era asylum seekers were differentiated from economic migrants. Both were understood as the victims of what Noll (2006) calls strong state persecution. The contemporary asylum seeker is transnational, a victim not only of the weak state's failure to offer protection but also of transnational conflicts that implicate the state offering safe haven. In many ways, the transnational asylum seeker is undifferentiated from the transnational economic migrant; both are victims of a form of globalization that does not offer protection without control. The difference is that a person who can prove persecution, etc rather than only economic hardship, can apply for asylum. Importantly, this is not the same as asking for justice or for human rights. Political asylum may have its foundations in issues of justice and human rights, but today it is not offered as a remedy for injustice. Instead, it provides a means for differentiating between the kinds of protection and controls states offer.

Political asylum seekers are transnational subjects forced into a national arena. ${ }^{8}$ The inconsistencies that asylum officials identify to challenge the credibility of asylum applicants are deep inconsistencies that begin with asking a person whose life has been destroyed to reconstruct it in the past and represent it as an ongoing (and stable) place one fears in the future. Segmenting that place out of the larger context of transnational conflict 
affords the asylum official some semblance of objective decision-making. The alternative would allow the flood-gates to open to all persons displaced because of injustice and violations of human rights. In a world increasingly divided between strong and weak, imagined hordes of migrants are the perceived threat that prompts the effort to differentiate between the economic migrant and the political asylum seeker. What the transnational definition of asylum does not include is the flight from economic deprivation or escape from a war torn country. The Afghans described by Ellick (2009) were fleeing the decades-long war in Afghanistan. Ellick describes one young man who lost his full-time job as a driver, and noted that the only other job he could find was a "once a week driving gig through Taliban territory. In the last eight months a suicide bomb and a firefight nearly took his life" (2009: 10). This Afghan is in the process of finding someone to smuggle him to Europe where he is planning to claim asylum. It is unlikely that the British asylum authorities will consider his case to fit into the narrow confines of the law and, thus, unlikely to grant him asylum.

The Afghan is an example of the involuntary migrant. The economic migrant is regarded as voluntary in contrast to the refugee who is forced by circumstances to leave. Aristide Zolberg defends this differentiation, which corresponds to a widely accepted definition of refugees as, "persons whose presence abroad is attributable to a well-founded fear of violence, as might be established by impartial experts with adequate information" (1989: 33).

As our research and the research of other political asylum scholars (ibid.: Bohmer and Shuman 2007; Schuster 2003) shows, it is in practice difficult to differentiate between voluntary and involuntary migrants; in a global economy, it is difficult to separate persecution from the kind of discriminatory practices that prevent people from working or sustaining themselves. Both asylum seekers and economic migrants move out of necessity. Little then is voluntary. The differentiation between economic migrants and asylum seekers depends on a deeper differentiation between national needs and transnational human rights. As Schuster (2003) and others have pointed out, economic migrants fill particular national needs. They are welcomed or denied entry depending on the need for particular kinds of labor. Schuster notes:

It is necessary to separate refugees from migrants in order to separate and control the different benefits each has to offer-the latter cheap labour or skills that are in short supply, the former, the moral legitimacy that comes from responding to the needs of strangers, from being generous that is, liberal (Schuster 2003: 37-8).

\section{Conclusion}

We have suggested several ways to understand the contradictory discourses of protection and control in political asylum practices. Historically, political 
asylum law was created to address fundamental violations of human rights during the Holocaust, but present-day asylum seekers represent a very different relationship between past and future persecution. Although human rights are articulated in universal terms, transcending national boundaries, protection of refugees is provided by nations. Political asylum is based on a transnational effort to provide a remedy when nations do not protect their own citizens. As we have pointed out, underlying this discourse of protection and failure to protect is a divide between western and non-western values as understood by liberal democracies. ${ }^{9}$ Refugees and people seeking asylum are admitted on humanitarian grounds. Admitting asylum seekers conforms to liberal democratic ideals of protection from persecution.

Asylum policies were first drafted, following WWII, in a climate of cultural relativism. As Marie-Bénédicte Dembour notes in her analysis of anthropology and human rights law, in 1947 the American Anthropological Association drafted an objection to the UN Declaration of Human Rights (written by Melville Herskovits) asking: "How can the proposed Declaration be applicable to all human beings, and not be a statement of rights conceived only in terms of the values prevalent in the countries of western Europe and America?"(1996: 18). Dembour points out that differentiating among societies that do or do not have human rights is a false distinction mirroring the false distinctions among societies that have or do not have legal systems. With particular relevance to our discussion, she argues that the difference between economic and political refugees is untenable. "The distinction economic and political refugees does not make sense in the light of the declared aim of human rights to provide a decent living for everyone, irrespective of their status" (1996: 22). She attributes the differentiation to the effort to control the number of people provided entry. Similarly, Liza Schuster argues, "States recognise an obligation to refugees that they do not extend to migrants, hence the insistence on discriminating between 'political' and 'economic' migrants" (2003: 24).

Dembour situates the contradiction in the relationship between individuals, law, and the state. She argues, "Although the ideology of human rights does away with the concept of the state to concentrate on the equal value of all human beings, its practice relies on the way in which individuals are classified in relation to a state" (1996: 23). She explains further that, "In human rights law, a rather strong dichotomy thus exists between civil and political rights on the one hand and social and economic ones on the other. International law privileges the former against the latter" (ibid.: 24). She argues that human rights are essentially outside the law: "In my view, human rights are (predominantly) extralegal not because they correspond to 'natural' moral rights but because they serve to articulate political claims which make sense in a particular social context" (ibid.: 26).

Political asylum seekers occupy a very curious place in the transnational landscape. To begin with, they are individuals who cannot rely on their citizenship to provide protection from their home countries. They are 
transnational subjects, requesting protection designed by transnational policies. In the context of transnational migration, political asylum applicants are, by definition, not able to call upon their states to defend them as citizens. They have rights, but not legal rights. ${ }^{10}$ To qualify for asylum, they are considered outside of, without regard to, either transnational politics or transnational economies. Instead, in an appeal to transnational human rights, they are granted protection in accord with liberal democratic values. Not just any violation of human rights qualifies for asylum.

The difficulty of making the distinction between people motivated by economics and people motivated by ideologies permeates not just discussions of migration but also discussions of transnational conflict more generally. We call attention to the difficulty when we describe children deployed to assist in foreign conflicts as victims of economic need. Not only can we not differentiate between civilians and soldiers, we can not differentiate between their motivations. Most of the discussions of contradictions in the political asylum process, rightfully attend to the difficulty or impossibility of making the distinction between the economic migrant and the political refugee. But at the personal level, the experiences of the political refugee are often quite different and depend, as we suggested above, on being in a state of exile, which depends on no less contradictory, but different, configurations between the transnational and the local.

Many asylum seekers described their experiences of dislocation, whether in their homeland as familiar people turned into enemies or at the border, where they relied on strangers and false passports and did not know where to go or what to do. In asylum hearings, they report further confusion and encounters with officials who not only lacked sympathy but expressed complete disregard in response to accounts of horrendous experiences. As we know, the officials occupy positions of disinterest out of necessity, as a dimension of equal treatment. For the asylum seeker, everything is experienced through the lens of exile and dislocation, so even the networks of assistance are tenuous. For some of the people we interviewed, what we might call transnational networks of belonging were immediately translated into local, immediate connections, always fragile, always tenuous, insofar as they were possible. A Cameroonian woman who sought asylum status in Great Britain said, "I have no friends; I cannot even trust friends. I don't even know where to start." Exile is the loss of the local and an ever-present longing for home. For political asylum seekers, the transnational may create new possibilities of belonging, but at all levels, the personal and the legal, it also means a loss of belonging.

\section{Biographical Notes}

Carol Bohmer is a Visiting Associate Professor in the Government Department of Dartmouth College. Her research interests include law as a social institution, 
gender, and immigration law and policy. She is the author with Amy Shuman of Rejecting Refugees: Political Asylum in the $21^{\text {st }}$ Century. She has also written The Wages of Seeking Help: Sexual Exploitation by Professionals (Westport, CT: Praeger Press) and Sexual Assault on Campus: The Problem and the Solution. with Andrea Parrot. (New York: Lexington Press)

Amy Shuman is Professor of Folklore at the Ohio State University where she holds positions in the departments of English, Women's Studies and Anthropology. Her research interests include narrative, feminist theory, and folklore. With Carol Bohmer she is the author of Rejecting Refugees: Political Asylum in the $21^{\text {st }}$ Century. She has also authored two books on narrative: Other People's Stories: Entitlement Claims and the Critique of Empathy (U of Illinois) and Storytelling Rights (Cambridge University Press).

\section{Notes}

${ }^{1}$ Interview conducted July 21, 2009.

${ }^{2}$ See Susan Coutin (2005).

${ }^{3}$ See Bohmer and Shuman (2007).

${ }^{4}$ The UK report is available at the following website:

http://www.homeoffice.gov.uk/rds/country_reports.html

${ }^{5}$ Gregory Noll discusses this problem of translation as the translation of culture into politics (2006).

${ }^{6}$ See TRAC reports: http://trac.syr.edu/immigration/reports/183/ TRAC reports that the discrepancy has been reduced somewhat in some places recently, but nevertheless they remain large.

${ }^{7}$ See, for instance, Article 13.2 Universal declaration of Human Rights, Article 12, International Convention on Civil and Political Rights (ICCPR).

${ }^{8}$ Nancy Fraser describes the more general problem of "forcibly imposing a national frame on proceses that are inherently transnational," which she calls "the problem of misframing" (2003: 92.)

${ }^{9}$ Schuster (2003:33) quotes David Jacobson who "argues that an adherence to human rights norms is compatible with strong nation-states. 'Human rights transcend, adapt, and transform the nation-state' 1996:3, they have 'become an essential means to international legitimacy' (1996:141n)."

${ }^{10}$ Hollifield (1992) and Sassen (1998) reintroduce the individual into migration theory, but this time as a rights bearing individual, whose rights insulate her/him from the arbitrary power of states.

\section{References}

Bohmer, Carol and Amy Shuman (2007) Rejecting Refugees: Political Asylum in the $21^{\text {st }}$ Century. New York, NY: Routledge.

Coutin, Susan Bibler (2005) Contesting Criminality: Illegal Immigration and the Spatialization of Legality. Theoretical Criminology 9(1):5-33.

Citizenship and Immigration Canada (2009) News Release. "Canada Imposes a Visa on Mexico.” July 13. http://www.cic.gc.ca/english/ department/media/releases/2009/2009-07-13.asp. 
Clifford, Tom. (2009) "Canada Says Ottawa Warned Prague of Move." The Prague Post. July 22. Http://www.praguepost.com/news/1768-calcott-saysottawa-warned-prague-of-move.html.

Dembour, Marie-Bénédicte (1996) "Human Rights Talk and Anthropological Ambivalence: The Particular Contexts of Universal Claims" in Olivia Harris, (ed.) Inside and Outside The Law: Anthropological Studies of Authority and Ambiguity, pp 19-40. London: Routledge.

Ellick, Adam B (2009) "Running Out of Options, Afghans Pay For an Exit." New York Times, July 5, 10.

Fraser, Nancy and Axel Honneth (2003) Redistribution or recognition? A political-philosophical exchange London, UK: Verso Books.

Khanna, Ranjana (2006) "Asylum Representing Culture, Translating Human Rights Symposium: Panel III: Asylum”, Texas International Law Journal 41:471-490.

Kneebone, Susan (2009) "Introduction: Refugees and Asylum Seekers in the International Context," in Susan Kneebone (ed.) Refugees, Asylum Seekers and the Rule of Law, pp 1-31. Cambridge, UK: Cambridge University Press.

Hollifield, James Frank (1992) Immigrants, Markets and States: The Political Economy of Postwar Europe. Cambridge, MA: Harward University Press.

Legomsky, Stephen H. (2009) "Refugees, Asylum and the Rule of Law in the USA, in Susan Kneebone (ed.) Refugees, Asylum Seekers and the Rule of Law, pp 122-170. Cambridge, UK: Cambridge University Press.

Macklin, Audrey (2009) "Asylum and the Rule of Law in Canada: Hearing the Other (Side), in Susan Kneebone (ed.) Refugees, Asylum Seekers and the Rule of Law, pp 78-121. Cambridge, UK: Cambridge University Press.

Noll, Gregor. (2006) "Asylum Claims and the Translation of Culture into Politics" Texas International Law Journal 41: 491-501.

O'Sullivan Maria (2009) “The Interaction between the International, the Regional and the Domestic: Seeking Asylum in the UK", in Susan Kneebone (ed.) Susan Kneebone (ed.) Refugees, Asylum Seekers and the Rule of Law, pp. 228-280. Cambridge, UK: Cambridge University Press.

Piot, Charles (2006) "Asylum and Culture: comments on Khanna and Noll," Texas International Law Journal 41: 503-506.

Sale v. Haitian Centers Council. 509 US 918 (1993) (No 92-528)

Saskia Sassen (2007). "Response," European Journal of Political Theory 6(4) 431444.

Schain, Martin A. (2008). The Politics of Immigration in France, Britain, and the United States. New York, NY: Palgrave Macmillan.

Schuster, Liza (2003) The Use and Abuse of Asylum in Britain and Germany. London: Routledge.

Shuman, Amy and Carol Bohmer (2004) "Representing Trauma: Political Asylum Narrative," Journal of American Folklore 117(466):394-414.

Uhlin, Anders (2008) "From Rights to Duties? Welfare and Citizenship for Immigrants and Refugees in Scandinavia." Paper presented at ISA Annual Meeting, San Francisco.

UNHCR (2009) "2008 Global Trends: Refugees, Asylum-Seekers, Returnees, 
Internally Displaced and Stateless Persons".

http://www.unhcr.org/4a375c426.html

USCIS (2006) Notice of Intention to Deny, August 30. (Letter to client whose name is withheld to protect identity). On file with author.

Zolberg, Aristede, and A. Suhrke and S. Aguayo (1989) Escape from Violence. New York, NY: Oxford University Press.

Carol Bohmer

Department of Government,

Dartmouth College, Hanover, NH 03755

Email:carol.bohmer@dartmouth.edu

Amy Shuman

Mershon Center for International Security

The Ohio State University

1501 Neil Ave, Columbus, Ohio 43201

email: shuman.1@osu.edu 